\title{
Çoklu Karar Verme Yöntemleri ile Alternatif Finansman Kararları ve Bir KOBI'́de Uygulama*
}

\section{Alternative financial resources with multiple decision making methods and application on a SME}

\author{
İrfan ERTUĞRUL ${ }^{1}$ a \\ Sibel VANLIOĞLU ${ }^{2}$
}

\begin{abstract}
${ }_{1}^{1}$ Pamukkale Üniversitesi, İktisadi ve İdari Bilimler Fakültesi, Denizli. iertugrul@pau.edu.tr ${ }^{2}$ UKİ Madencilik Ltd. Şti., Muhasebe-Finans Müdürü, Antalya. sibelvanlioglu@gmail.com

a Yazışılan yazar/Corresponding author
\end{abstract}

\begin{abstract}
Özet
Bütün ülkelerin ortak amaçları ekonomik anlamda kalkınmak ve gelişmektir. Ülkeler bireylerin refah seviyesini ve istihdamın artırmak istemektedirler. Her geçen gün artan rekabet ortaminda işletmeler devamlilıkların sürdürebilmek için uygun finansman kaynaklarına ulaşmak durumundadır. Özellikle yeni kurulan ve büyümekte olan işletmeler açısından alternatif finansman araçları büyük önem taşımaktadır. İşletmelerin alternatiflerinin artmasılyla karar vermeleri de zorlaşmaktadır. İşletmeler karar verebilmek için çeşitli yöntemlerden faydalanmaktadırlar. Birden fazla kriterin bulunduğu durumlarda çoklu karar verme yöntemleri ile çok sayıda alternatif arasından seçim yapabilmektedir. Çalışmanın uygulama bölümünde orta ölçekli bir işletmenin iş makinası almak için tercih ettiğ i alternatif finansman aracı leasing firmasının seçiminde AHP ve TOPSIS yöntemleri ile çözüm aranmıştır.
\end{abstract}

Anahtar kelimeler: Çok Kriterli Karar Verme, Alternatif finansman araçları, TOPSIS, AHP, Leasing

JEL kodları: C44, G23

\begin{abstract}
The common objective of all countries are to economic development and progress. Countries target to increase the employment and the welfare of the individiuals. Businesses have to reach the suitable financial resources in the rising competitive area. The alternative financial resources are very crucial for those especially newly founded and growing enterprises. Taking decision is getting diffucult for enterprises because alternative sare increasing. The enterprises benefit from a variety of methods to decide. Incase of more than one criteria, it can choose from the alternatives by multiple decision making methods. In the applied studies, AHP and TOPSIS method chosen by leasing company were applied for he solution where a medium-sized enterprises choose leasing financing as an alternative financing to buy heavy construction equipment.
\end{abstract}

Keywords: Decision Making with Multi Criteria, Alternative financial resources, TOPSIS, AHP, Leasing

JEL codes: C44, G23

\footnotetext{
* Bu makale Prof. Dr. İrfan ERTUĞRUL danışmanlığında Sibel VANLIOĞLU tarafından savunulan "Çoklu Karar Verme Yöntemleri ile Alternatif Finansman Kararları ve Bir Kobi'de Uygulama" isimli yüksek lisans tez çalışmasından faydalanılarak hazırlanmıştır.
} 


\section{GİRIŞ}

Günümüze firmaların ihtiyacına uygun finansman aracına karar vermeleri ve sonrasında alternatifleri kıyaslamaları gerekmektedir. Yani doğru ve etkin karar verme firma için önemli olan bir diğer problemdir. Bu çalışmada ilk önce, karar verme ve yöntemleri ele alınmıştır. Karar verme, karar verme süreci ile çoklu karar verme yöntemleri anlatılarak daha sonra çalışmada finansman sorunları için alternatif finansman araçları tanımlanmıştır. Son olarak çalışmada uygulama olarak maden sektöründe faaliyet gösteren bir işletmede leasing firması seçim problemi ele alınmıştır. Problem çözümünde AHP ve TOPSIS yöntemleri kullanılmıştır. Ayrıca, sonuçların değerlendirilmesinin yanı sıra yöntem adımları arasındaki fark ve benzerliklerden bahsedilmiştir. Yöntemlerin uygulanabilir olup olmadığına yer verilmiştir. Elde edilen sonuçlar doğrultusunda bundan sonraki çalışmalarda çoklu karar verme tekniklerinin finansman kararlarında kullanılabilirliği konusuna değinilmiştir.

\section{KARAR VERME VE SÜRECI}

İşletmelerde karar verme, yönetsel başarı için anahtardır (McGuigan vd., 1996: 5). Karar verme problemi; bir alternatif kümesinden en az bir amaç veya ölçüte göre en uygun alternatifin seçimi şeklinde tanımlanmaktadır. Karar alma, işletmelerin önemli kalemlerindendir. Bu süreç büyük oranda zaman ve maliyet gerektirmektedir. $\mathrm{O}$ zaman; karar vericiler, alternatifler, kriterler, sonuçlar, çevre ve karar vericinin özellikleri karar problemi elemanları olarak sıralanabilir. Bir karar problemi bir amaç veya ölçüte göre alternatifler arasından bir seçim yapma şeklinde de tanımlanabilir (Dağdeviren ve Eren, 2001: 2-52). Karar verme bir işletmenin yapıtaşlarındandır. Dolayısıyla, rekabette avantaj sağlama ve sürdürmek için doğru kararların alınması gereklidir (Kuruüzüm ve Atsan, 2001: 84).

Kişilerin çeşitli nedenlerle bir araya geldikleri organizasyonların amaçlarına ulaşma doğrultusunda yürüttükleri faaliyetlerde her gün birçok sorunla karşılaşılmaktadır. Bu sorunları çözmekle yükümlü kişiler ise karar verici olarak adlandırılmaktadır (Yaralıoğlu, 2010: 2). Diğer bir deyişle, karar verme sorumluluğunu yüklenen kişi veya gruba karar verici denir (Erdoğmuş, 2003: 1). Bu karar vericiler sistemin durumundan memnun veya tatmin olmadıkları durumda çareler ararlar ve problem olan noktaları bulmaya çalışırlar (Karayalçın, 1979: 19). Karar verme, karşılaşılan durum ile ilgili istenilen sonuçlara ulaşabilmek için yol gösteren bilgilerin toplanması, bu bilgiler doğrultusunda sistematik, bilimsel ve mantıklı akıl yürütme ile alternatifler oluşturup bu alternatiflerden en uygun olanına seçme sürecidir (Tosun, 1990: 310)

Karar verme sürecine analitik olarak yaklaşabilmek için bir kararı oluşturan temel öğelerin belirlenmesi gerekmektedir (Gülenç ve Karabulut, 2005: 56). Süreci etkileyen faktörler vardır. Karar verici, doğa koşulları, amaçlar, seçenekler, seçeneklerin sonuçları arasında seçim yapılması, gibi faktörler karar verme sürecini etkileyen faktörler arasında sıralanabilir (Tekin, 1999: 17).

\section{3. ÇOKLU KARAR VERME}

Karar verici karar noktaları arasından yapacağı seçimde eğer tek bir değerlendirme faktörüne sahipse, değerlendirme faktörünün niteliğine göre en büyük avantajlı ya da en küçük dezavantajlı olan karar noktasını kolaylıkla seçebilir. 
Ancak karar ortamları ya da süreçleri her zaman bu kadar kolay olmayabilir. Karar verici vereceği kararlarda genelde, karlılık, maliyet, zaman gibi çok sayıda, özelikle de amaç yönleri farklı değerlendirme faktörlerini kullanmak ve karar noktaları üzerindeki seçimini bu faktörlere göre yapmak zorunda kalabilir. Bu durumda bir karar noktası bir değerlendirme faktörüne göre en iyi iken, başka bir değerlendirme faktörüne göre başka bir karar noktası en iyi olabilir. Bu değerlendirme faktörlerinin karar verici açısından önem değerleri farklı olsa bile, tek yanlı bir karar nedeniyle diğer karar noktaları karar verici açısından tam anlamıyla kaçırılmış fırsatlar olacaktır. Sonuç ise karar verici açısından hem pişmanlık hem de karar yerine kararsızlık olacaktır (Yaralıŏlu, 2010: 13).

\subsection{TOPSIS}

Çoklu karar verme problemi ' $\mathrm{n}$ ' sayıda alternatifi ve ' $\mathrm{m}$ ' sayıda kriteri olan $\mathrm{m}$ boyutlu uzayda n noktaları ile gösterilebilmektedir. Hwang ve Yoon'a göre (1981) alternatif çözüm noktasının pozitif-ideal çözüme en kısa ve negatif-ideal çözüme en uzak mesafede olacağ1 düşünülerek oluşturulmuştur. Sonrasında bu düşünce Lai, Lui ve Hwang (1994) tarafından daha da geliştirilmiştir (Eleren ve Karagül, 2008: 6). TOPSIS yönteminde ideal çözüme en kısa, negatif ideal çözüme en uzak mesafedeki alternatifin en iyi alternatif olduğu düşünerek yapılır (Urfalığlu ve Genç, 2013: 336).

Aşağıda TOPSIS yönteminin uygulama basamakları tanımlanmıştır.

Adım 1: Karar Matrisinin ( $A$ ) Oluşturulması

Karar matrisinin satırlarında üstünlükleri sıralanmak istenen karar noktaları yer alırken sütunlarında ise karar vermede kullanılacak değerlendirme faktörleri yer alır. A matrisi karar verici tarafından oluşturulan başlangıç matrisidir ve aşağıdaki gibi gösterilir:

$A_{i j}=\left[\begin{array}{cccc}a_{11} & a_{12} & \ldots & a_{1 n} \\ a_{21} & a_{22} & \ldots & a_{2 n} \\ \cdot & & & \cdot \\ \cdot & & & \cdot \\ \cdot & & & \cdot \\ a_{m 1} & a_{m 2} & \ldots & a_{m n}\end{array}\right]$

$A_{i j}$ matrisinde $m$ karar noktası, $n$ değerlendirme faktörü sayısını gösterir (Yaralıŏlu, 2010:23).

Adım 2: Normalize Edilmiş Karar Matrisinin $(R)$ Oluşturulması

A matrisinin elemanlarından yararlanılarak ve formül (2) kullanılarak hesaplanır (Dumanoğlu ve Ergül, 2010: 106).

$r_{i j}=\frac{a_{i j}}{\sqrt{\sum_{i=1}^{m} a_{i j}^{2}}} \quad \mathrm{i}=1, \ldots, \mathrm{m} \quad \mathrm{j}=1, \ldots, \mathrm{n}$ 
$R$ matrisi aşağıdaki şekilde elde edilmektedir.

$$
R_{i j}=\left[\begin{array}{cccc}
r_{11} & r_{12} & \ldots & r_{1 n} \\
r_{21} & r_{22} & \ldots & r_{2 n} \\
\cdot & & & \cdot \\
\cdot & & & \cdot \\
\cdot & & & \cdot \\
r_{m 1} & r_{m 2} & \ldots & r_{m n}
\end{array}\right]
$$

Adım 3: Ağırlıklı Standart Karar Matrisinin ( $V)$ Oluşturulması

Ağırlık değerleri $\left(w_{j}\right)$ belirlendikten sonra $\left(\sum_{j=1}^{n} w_{j}=1\right) R$ ile $V$ matrisi oluşturulur.

$$
V_{i j}=\left[\begin{array}{cccc}
w_{1} r_{11} & w_{2} r_{12} & \ldots & w_{n} r_{1 n} \\
w_{1} r_{21} & w_{2} r_{22} & \ldots & w r_{2 n} \\
\cdot & & & \cdot \\
\cdot & & & \cdot \\
\cdot & & & \cdot \\
w_{1} r_{m 1} & w_{2} r_{m 2} & \ldots & w_{n} r_{m n}
\end{array}\right]
$$

Adım 4: İdeal $\left(A^{+}\right)$ve Negatif İdeal $\left(A^{-}\right)$Çözümün Belirlenmesi

$\mathrm{Bu}$ adımda ağırlıklı standart karar matrisinin her bir kolonunda yer alan maksimum ve minimum değerler belirlenir.

$$
\begin{aligned}
& A^{+}=\left\{v_{1}^{+}, v_{2}^{+}, \ldots, v_{n}^{+}\right\} \text {(maksimum değerler) } \\
& A^{-}=\left\{v_{1}^{-}, v_{2}^{-}, \ldots, v_{n}^{-}\right\} \text {(minimum değerler) }
\end{aligned}
$$

Adım 5: Alternatifler Arasındaki Mesafe Ölçülerinin Hesaplanması

İdeal değerler belirlendikten sonra 5. adımda ideal ve negatif ideal çözüme olan uzaklıklar hesaplanmaktadır (Mahmoodzadeh vd., 2007: 337).

$$
\begin{array}{ll}
S_{i}^{+}=\sqrt{\sum_{j=1}^{n}\left(v_{i j}-v_{j}^{+}\right)^{2}} & \mathrm{i}=1,2, \ldots, \mathrm{m} \\
S_{i}^{-}=\sqrt{\sum_{j=1}^{n}\left(v_{i j}-v_{j}^{-}\right)^{2}} & \mathrm{i}=1,2, \ldots, \mathrm{m}
\end{array}
$$

$S_{i}^{+}$ve $S_{i}^{-}$sayısı karar noktası sayısı kadar olacaktır. 
Adım 6: İdeal Çözüme Göreli Yakınlığın Hesaplanması

İdeal ve negatif ideal çözüme uzaklık ölçüleri yardımı ile her bir karar noktasının ideal çözüme yakınlığı $\left(C_{i}^{+}\right)$hesaplanır. Buradaki ölçüt, negatif ideal ayırım ölçüsünün toplam ayırım ölçüsü içindeki payıdır. İdeal çözüme göreli yakınlık formül (9) ile hesaplanır (Ballı ve Korukoğlu, 2009: 125).

$C_{i}^{+}=\frac{S_{i}^{-}}{S_{i}^{-}+S_{i}^{+}} \quad \mathrm{i}=1,2, \ldots, \mathrm{m}$

$C_{i}^{+}, 0 \leq C_{i}^{+} \leq 1$ aralığında değer almaktadır. Elde edilen değerler büyüklüğüne göre sıralanarak alternatiflerin önem sıraları belirlenir.

\subsection{Analitik Hiyerarşi Prosesi}

Analitik Hiyerarşi Prosesi (AHP) Profesör Thomas L. Saaty (1977) tarafından 1970'lerde çok kriterli problemlerin çözümünde kullanılmak üzere geliştirilmiş olan bir karar verme yöntemidir. AHP birçok karar verme probleminde kullanılan geniş bir uygulama alanına sahiptir (Kuruüzüm ve Atsan, 2001: 84). AHP'de faktörler hiyerarşik olarak düzenlenerek ve karar alternatifleri için ikili karşılaştırılmaları yapılarak elde edilen özelliklere göre alternatiflerin puanları hesaplanır (Ertuğrul, 2003: 12).

AHP'nin tercih edilmesinin sebebi çok kriterli kararların alınmasında öznel kriterleri dikkate alabilmesidir. Nitel faktörlerin önemli olduğu $\mathrm{AHP}^{\prime}$ de alternatiflerin değerlendirilmesinde sayısal ve nitel faktörleri birlikte kullanan bir tekniktir (Rouyendegh ve Erkan, 2010: 78).

Karar problemlerinde alternatiflerin değerlendirilmesi çok sayıda kriterin olması ve karara eşit etkilerinin olmaması yani kriterlerin önem ağırlıklarının farklı olması durumunda, alternatiflerin sıralamasını yapabilmek için AHP ile her bir kriterin alternatiflerinin ikili karşılaştırmaları yapılır (Dündar, 2008: 219).

AHP, belirlilik ve belirsizlik ortamında birden fazla alternatif arasından seçim yaparken, birden fazla karar vericinin olduğu, çok faktörlü ve amaçlı karar verme probleminde kullanılır. AHP, rasyonel veya irrasyonel tercihleri ve sezgisel kararları da sürece dâhil edebilmek için kapsamlı çerçeve sunar (Saat, 2000: 150). AHP ile çözümlemenin adımları aşağıdaki gibidir (Yaralıŏ̆lu, 2001: 131-134; 2010: 42-49):

Adım 1: Her yöntemde olduğu gibi problem tanımlanır. Problemin tanımlanması, iki aşamadan oluşur. Birinci aşama karar noktaları belirlenir, ikinci aşamada ise karar noktalarını etkileyen faktörler belirlenir. Karar noktalarının sayısı m ile gösterilirken, karar noktalarını etkileyen faktör sayısı ise $\mathrm{n}$ ile gösterilmiştir. İkili karşılaştırmaların tutarlı ve mantıklı olmasını doğru belirlenecek faktör sayısı ve faktörlerin tanımlarının detaylı yapılması önemli derecede etkileyecektir.

Adım 2: nxn boyutlu kare bir matris olan ikili karşılaştırmalar matrisinin köşegeni her zaman 1 değerini alır. 


$$
A=\left[\begin{array}{cccc}
a_{11} & a_{12} & \ldots & a_{1 n} \\
a_{21} & a_{22} & \ldots & a_{2 n} \\
\ldots . & \ldots & \ldots & \ldots \\
a_{n 1} & a_{n 2} & \ldots & a_{n n}
\end{array}\right]_{n x n}
$$

İlgili faktör kendisi ile karşılaştırıldığı için matrisin köşegeni 1 değerini almaktadır. Çünkü karşılaştırmalar her faktörün kendisi ve diğer faktörlerin birbirleriyle olan üstünlüklerine göre oluşturulmaktadır. Faktörlerin bu karşılaştırılmalarında Tablo 1'deki AHP temel ölçek önem skalası kullanılır.

Bir örnekle açıklanacak olursa 1. faktör 2. faktör karşılaştırması yapılırken karar verici daha üstün gördüğ ü faktöre bir değer verir, diyelim ki 1. faktörü 2. faktöre göre 4 kat daha üstün görüyor ise 1.satır ile 2.sütun bileşenine 4 değerini verecektir. Tam tersi söz konusu ise yani 2.faktörün daha üstün olduğunu düşünüyor ise aynı sütun bileşeni bu sefer $1 / 4$ değerini alacaktır. Eğer faktörlerin birbirine karşı üstünlüklerinin olmadığ1 düşüncesi varsa da bu defa da bileşen 1 değerini alacaktır.

Karşılaştırmalar yapılırken değerler 1 olan köşegen değerinin üst bileşenleri için verilir alt bileşenler için (11) numaralı formül kullanılarak tamamlanır.

$a_{j i}=\frac{1}{a_{i j}}$

Yani örnekten yola çıkılırsa 1.satır 2.sütun bileşeni 4 değerini alırken matrisin 2.satır 1.sütun bileşeni de $1 / 4$ değerini alır.

Tablo 1. Önem Skalası

\begin{tabular}{|c|l|}
\hline Önem Değerleri & Değer Tanımları \\
\hline 1 & Her iki faktörün eşit öneme sahip olması durumu \\
\hline 3 & Birinci faktörün ikinci faktörden daha önemli olması durumu \\
\hline 5 & Birinci faktörün ikinci faktörden çok önemli olması durumu \\
\hline 7 & $\begin{array}{l}\text { Birinci faktörün ikinci faktöre nazaran çok güçlü bir öneme sahip olması } \\
\text { durumu }\end{array}$ \\
\hline 9 & $\begin{array}{l}\text { Birinci faktörün ikinci faktöre nazaran mutlak üstün bir öneme sahip olması } \\
\text { durumu }\end{array}$ \\
\hline $2,4,6,8$ & Ara değerler \\
\hline
\end{tabular}

Adım 3: Faktörlerin yüzde önem dağılımları belirlenir. Karşılaştırma matrisi faktörlerinin bir önceki adımda birbirlerine olan üstünlük seviyeleri belli bir mantık çerçevesinde gösterilmiştir. Yüzde önem dağılımlarını yani her bir faktörün bütün içindeki ağırlıklarını belirlemek için karşılaştırma matrisi sütun vektörlerinden yararlanılarak formül (13) ile (14)'deki $B$ sütun vektörü elde edilir. 


$$
\begin{gathered}
B_{i}=\left[\begin{array}{c}
b_{11} \\
b_{21} \\
\ldots \\
b_{n 1}
\end{array}\right]_{n \times 1} \\
b_{i j}=\frac{a_{i j}}{\sum_{i=1}^{n} a_{i j}}
\end{gathered}
$$

Bu işlemler her bir faktörler için de tekrarlandığında faktör sayısı (n) kadar $B$ sütun vektörü elde edilecektir. Bu sütun vektörleri bir matris halinde bir araya getirildiğinde ise aşağıdaki tanımlanan nxn boyutlu $C$ matrisi oluşur.

$C=\left[\begin{array}{cccc}b_{11} & b_{12} & \ldots & b_{1 n} \\ b_{21} & b_{22} & \ldots & b_{2 n} \\ \ldots & \ldots & \ldots & \ldots \\ b_{n 1} & b_{n 2} & \ldots & b_{n n}\end{array}\right]_{n x n}$

$C$ matrisinden faydalanarak, faktörlerin yüzde önem dağılımlarını elde etmek için $C$ matrisini oluşturan satır bileşenlerinin aritmetik ortalaması alınarak öncelik vektörü W sütunu elde edilir. Öncelik vektörünün elde edilişi aşağıda tanımlanmıştır.

$$
w_{i}=\frac{\sum_{j=1}^{n} c_{i j}}{n}
$$

Adım 4: Faktör kıyaslamalarındaki tutarlılık ölçülür. AHP karar vericinin faktörler arasında yaptığı bire bir karşılaştırmalardaki tutarlılığa bağlı olacağından kendi içinde ne kadar tutarlı bir sistematiği olursa olsun sonuçların gerçekçiliği için tutarlılık ölçümü yapılmalıdır. AHP tutarlılığın ölçülebilmesi için süreç sonucunda elde edilen Tutarlılık Oranı $(C R)$ ile bulunan öncelik vektörünün ve dolayısıyla faktörler arasında yapılan birebir karşılaştırmaların tutarlılığın test edilebilmesi imkânını sağlamaktadır. AHP modelleri ile verilecek son kararın güvenilirliği ile yakından ilişkili olan bir faktör olarak, karar vericinin ikili karşılaştırmalar sırasında tutarlı davranılmaktadır. Bu yüzden tutarlılık sorunu ile ilgili olarak AHP yönteminde karar vericinin karşılaştırma sonuçlarına paralel olarak bir "tutarlılık derecesi belirleme" hesaplama yöntemi geliştirilmiştir. İkili karşılaştırma matrisleri için AHP metodunda Tutarlılık Oranı (T.O. yada Consistency Ratio, C.R.) hesaplanır. 0,10 ve altında olan oran problemin çözümüne devam edebilmek için tutarlı kabul edilebilir niteliktedir (Saaty, 1988: 440). AHP, Tutarlılık Oranını, faktör sayısı ile $A$ karşılaştırma matrisi ile $W$ öncelik vektörünün matris çarpımından $D$ sütun vektörünün elde edilmesiyle hesaplanan Temel Değer $(\lambda)$ bir katsayının karşılaştırılmasıyla hesaplanır. 
$D=\left[\begin{array}{cccc}a_{11} & a_{12} & \ldots & a_{1 n} \\ a_{21} & a_{22} & \ldots & a_{2 n} \\ \cdot & & & \cdot \\ \cdot & & & \cdot \\ \cdot & & & \cdot \\ a_{n 1} & a_{n 2} & \ldots & a_{n n}\end{array}\right] x\left[\begin{array}{c}w_{1} \\ w_{2} \\ \cdot \\ \cdot \\ w_{n}\end{array}\right]$

$E_{i}=\frac{d_{i}}{w_{i}} \quad(\mathrm{i}=1,2, \ldots, \mathrm{n})$

Formülde tanımlandığı gibi elde edilen $D$ sütun vektörü ile $W$ öncelik vektörünün karşılıklı elemanlarının bölümünden her bir değerlendirme faktörüne ilişkin temel değer $(E)$ elde edilir. Bu değerin aritmetik ortalaması ise karşılaştırmaya ilişkin temel değeri $(\lambda)$ verir.

$\lambda=\frac{\sum_{i=1}^{n} E_{i}}{w_{i}}(\mathrm{i}=1,2, \ldots, \mathrm{n})$

$\lambda$ hesaplandıktan sonra Tutarlılık Göstergesi (CI) (19) formülünden yararlanılarak hesaplanabilir.

$C I=\frac{\lambda-n}{n-1}$

Son aşamada ise $C I$, Random Gösterge $(R I)$ olarak adlandırılan standart düzeltme değerine bölünerek $C R$ oranı elde edilir. Faktör sayısına karşılık gelen değerler seçilir.

Tablo 2. RI Değerleri

\begin{tabular}{|c|c|c|c|}
\hline $\mathbf{N}$ & $\mathbf{R I}$ & $\mathbf{N}$ & $\mathbf{R I}$ \\
\hline 1 & 0 & 7 & 1,41 \\
\hline 2 & 0 & 8 & 1,45 \\
\hline 3 & 0,58 & 9 & 1,49 \\
\hline 4 & 0,90 & 10 & 1,51 \\
\hline 5 & 1,12 & 11 & 1,48 \\
\hline 6 & 1,24 & 12 & 1,56 \\
\hline
\end{tabular}

$C R=\frac{C I}{R I}$

Karar matrisinin tutarlı olduğunu söyleyebilmek için hesaplanan $C R$ değerinin 0.10 'dan küçük olmasını istenir. $C R$ değeri 0 'a yaklaştıkça sonuçlar daha tutarlı, 0.10 'dan büyük ise hesaplama hatası ya da karar vericinin tutarsız karşılaştırma değerleri verdiğini gösterir.

Adım 5: Her bir faktör için, m karar noktasındaki yüzde önem düzeyleri bulunur. Bu aşamada bir önceki adımdaki gibi karar noktalarının her bir faktör açısından yüzde önem dağılımları belirlenir yani faktör sayısı kadar birebir karşılaştırmalar ve matris işlemleri tekrarlanır. Her bir karşılaştırma işleminden sonra değerlendirilen faktörün karar 
noktalarına yüzde dağılımlarını gösteren $S$ sütun vektörleri elde edilir. Bu sütun vektörleri aşağıdaki formülde tanımlanmıştır.

$$
S_{i}=\left\lfloor s_{j i}\right\rfloor_{m x 1} \quad \mathrm{i}=1,2, \ldots \mathrm{n} ; \mathrm{j}=1,2, \ldots, \mathrm{m}
$$

Adım 6: Karar noktalarındaki sonuç dağılımı bulunur. Bu adımda öncelikle, yukarıda bahsedilen $S$ sütun vektöründe meydana gelen $K$ karar matrisi oluşturulur.

$$
K=\left\lfloor s_{i j}\right\rfloor_{m x n}
$$

Sonuç olarak karar matrisi $W$ sütun vektörü ile çarpılarak Formül (23) karar noktalarındaki yüzde dağılım elde edilir.

$\left[s_{i j}\right]_{m \times n} x\left[w_{i}\right]_{n x 1}$

\section{LEASING}

Leasing'in kelime anlamı "kiralama"dır. Yatırım finansmanlarında kullanılan öz kaynak, satıcı kredisi ve banka kredilerine alternatif olan bir finansman aracıdır (YapıKredi Leasing A. O., 2016). Leasing, kiracının yatırım için seçilmiş olan malının mülkiyetinin finansal kiralama şirketinde kalacak şekilde, yapılan sözleşmenin süresi içinde ödenecek kiralar karşılığ1 kullanım hakkının kiracıda kalmasına imkân veren bir finansman yöntemidir (Garanti Finansal Kiralama A. Ş., 2016). Avrupa Leasing Birliği'nin tanımına göre finansal kiralama, kiralayan ve kiracı arasında düzenlenen belirli bir sözleşme süresi için, üreticiden kiracının seçtiği taşınır veya taşınmazın kiralayan tarafından satın alınarak mülkiyet hakkının kiralayanda, kullanım hakkının ise kiracıda kalmasını sağlayan bir yöntemdir (Toroslu, 1999: 11).

Herhangi bir varlığı edinmek isteyen bir işletmenin seçeneklerinden biri olan kiralama, varlığa yatırım yapmanın neden olacağı nakit çıkışlarını erteleyen ve eldeki sınırlı kaynağın daha etkin kullanımına imkân tanıyan bir seçenektir (Özulucan ve Özdemir, 2009: 26). Firma açısından fon sağlamanın temel amacı, faaliyeti için gerekli iktisadi varlıkların elde edilmesidir. Firmanın duran varlıklara gereksinmesi varsa, bunun orta ve uzun süreli fonlarla finanse edilmesi gerekmektedir. İşletme hizmetlerinden faydalanmak için gereksinim duyduğu duran varlıkların mülkiyet hakkına sahip olmaktan çok kullanım haklarından doğan karı amaçlıyorsa makine ve teçhizatı satın almaktansa kiralamayı tercih eder. Kiralama da, taşınır ve taşınmaz varlıkların hizmetlerinden yararlanılmasına olanak veren bir araçtır (Akgüç, 1998: 617).

\subsection{Leasing'in Tarafları, Unsurları ve İşleyişi}

Finansal kiralama (Leasing) sözleşmesinde: 1) Kiralayan, 2) Kiracı ve 3) Mal sahibi olmak üzere üç taraf vardır. 1) Kiralayan (Finansal kiralama şirketi): malın maliki, malın zilyetliğini kiracıya devredecek ve bu konuda yetkili olacak. 2) Kiracı (Gerçek veya tüzel kişi): Malı beğenip seçecek, kira bedelini ödeyecek, maldan yararlanacak. 3) Mal Sahibi (Finansal kiralamaya konu olan malı sağlayan kuruluş). Finansal kiralama bu üç tarafın da dâhil olduğu unsurlara sahiptir. Bunlar: Kira: Kiracı'nın Kiralayan'a, leasinge konu malın kullanım hakkı için sözleşme ile belirlenen periyodik ödemelerdir. Sözleşme: Leasing işlemine konu 
olan malın kullanım hakkının kiracı ile kiralayan arasında, kiracıya devri ve kira bedellerinin, bütün şartların belirtildiği yazılı anlaşmadır. Sözleşmenin Süresi: Sözleşmeler aksi belirtilmediği sürece 4 yillık düzenlenir. Teknolojik ve amortisman süreleri kısa olan mallarda sözleşme süresi 4 yıldan kısa düzenlenebilir fakat 2 yıldan da kısa olamaz. 4 yıldan kısa süreli sözleşmeler ancak Bakanlar Kurulunca belirlenmektedir. Sözleşmenin Şekli Tescili: Taşınıra ait düzenlenen sözleşmeler kiracının ikametgâhındaki noterlik huzurunda imzalanarak özel sicile tescil edilir. Ancak taşınmaz mala ilişkin sözleşmeler taşınmazın bulunduğu tapu müdürlüğünce, gemilere ilişkin sözleşmeler ise gemi sicilinde şerh edilir. Yurtdışında olan kiralayan şirketin eğer Türkiye'de bir şubesi bulunmuyorsa sözleşmeler Hazine ve Dış Ticaret Müsteşarlı̆̆g'nın bağlı olduğu Bakanlık tarafından tescil edilir (Kaya, 2012: 283-284). Taraflar ve unsurlar kapsamında işleyiş şu şekildedir:

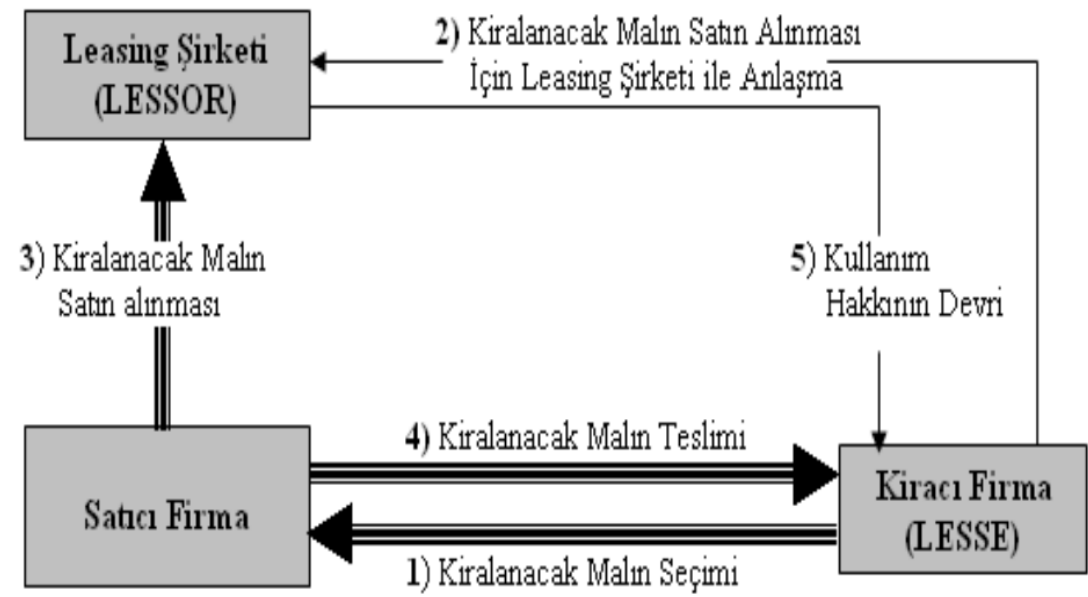

Şekil 1. Leasing Sürecinin İşleyişi

Kaynak: Ceylan, A. (2003: 112).

Sözleşme süresince kiracı finansal kiralamaya konu olan malın kullanım hakkına sahip olup, sözleşmeye uygun olarak her türlü faydayı elde etme hakkına sahiptir. Kiracl, kiralamaya konu olan malı sözleşme hükümleri çerçevesinde kullanmaya dikkat etmek zorundadır. Sözleşme süresince malın her türlü hasar ve zarar mesuliyeti kiracıya ait olduğu gibi sözleşmede farklı beyan olmadığı takdirde bütün bakımı, koruması ve onarımı da kiracıya aittir (Akgüç, 1998: 628-629). Mülkiyet hakkı kendisinde olan kiralamaya söz konusu olan malı kiralayan şirket sigortalatmak zorundadır ancak primlerin ödemesi kiracıya aittir. Normal şartlarda sözleşme sürenin sona ermesiyle son bulur. Kiracı kiraları süresinde ödemediği takdirde kiralayan ihtarname ile sözleşmeyi feshedebilme hakkına sahiptir. Eğer kiralayan şirket aleyhinde bir hukuki işlem başlatılırsa kiralamaya konu mal ya da mallar sözleşmenin süresi içinde haczedilemez. Leasing işlemlerinde sözleşmenin süresi sona erdiğinde kiralanan malın kiracıya devredilip edilmeyeceği sözleşmede belirtilmiştir. Menkullerin özelliğine göre devir işlemleri farklılık göstermektedir (Kaya, 2012: 284-285).

\subsection{Leasing'in Çeşitleri}

Leasing, uygulamada çok değişik şekiller almaktadır. Bunları leasing türleri olarak adlandırabiliriz. Bu sınıflama içinde en önemlisi İşletme leasing'i ve Finansal leasing'tir. Buna göre: 
1. İşletme (Hizmet-Faaliyet) Leasing'i (Operational Leasing): Literatürde "renting", "günlük işlem leasingi", "kısa vadeli leasing", "servis kiralaması" olarak da isimlendirilen faaliyet kiralamasında, kiraya konu fiziksel varlık, bir kira anlaşmasıyla ekonomik ömrünü kapsamayan finansal kiralamaya göre daha kısa bir süre için kiralanmasıdır (Çondur vd., 2008: 7). Bu tür leasing vade açısından kısa sürelidir. Kira konusu olan mal ve teçhizatın tüm ömrünü kapsamaz. Anlaşmanın belirli süreyi kapsamak üzere yapılmasına rağmen, önceden bildirilen süreler içinde ihbar yapılmak şartıyla sözleşme fesih edilebilir (Ulukanlı, 1996: 34).

Bu leasing türünde kiracı kiralanan malın bedelinin genel olarak \%80'ini veya daha azını öder. Kiralayan kiralanan malla ilgili riski \%20 civarındadır, kiralayan finansmanın yanında kiralanan malla ilgili ikinci el değer riski taşır. Kiralayan şirket ekonomik maliktir ve sözleşme hak ve yükümlülükleri kiracının bilançosuna yansımaz. Kiralama süresi amortisman süresine yakın olur. Kiralanan malın teknolojisi çabuk değiş̧iyor ise kiralanan mal genel olarak iade edilir. Teknolojisi çabuk değişmeyen mallar genel olarak kira dönemi sonunda rayiç değerden kiracı tarafından satın alınır veya rayiç bedel üzerinden yeniden kiralanir (Akbulut, 2004: 16).

2. Finansal Leasing (Financial Leasing): Sermaye kiralaması adı da verilen finansal kiralama; kiralanan malın mülkiyet hakkının kiralayanda kalmasına rağmen, kullanım hakkının kiracıda kaldığı bir kiralama yöntemi olarak kiracıya varlığın ekonomik ömrü süresince kullanma yetkisi veren uzun süreli leasing türüdür (Söyler, 2007: 25). Kiracı kiralanan malı satın almaya yönlendirilir ve mal genel olarak baştan belirlenen bir (düşük) bedelle kiracı tarafından satın alınır. Mal bedeli ve finansman maliyetinin tamamı kira bedeli olarak ödenir (full-payout). Bu nedenle kiracı ekonomik maliktir ve kira sözleşmesinin hak ve yükümlülükleri kiracının bilançosuna yansır. Sözleşmelerin fesih edilemezlik süresi kiralanan malın amortisman süresine eşittir veya büyüktür. Net kiralamadır (sadece finansman sağlanır ilave servis sağlanmaz). Türkiye'deki tüm leasing işlemleri bu kategoridedir (Akbulut, 2004: 15).

\subsection{Leasing'in Ekonomik Etkileri, Avantajları ve Dezavantajları}

Leasing, kiracı tarafından seçilen malın finansal kiralama şirketince satın alınıp kiralanarak, kiralama süresinin sona ermesiyle mülkiyet hakkının da devredilmesi şeklinde yapılır. Bu sebeple leasing, mal alımlarında şirketlere önemli avantajlar sağlamaktadır. Sözleşme süresi içinde söz konusu malın mülkiyet hakkının Finansal Kiralama şirketinde kalması sebebiyle asgari teminatlar ile uzun vadeli finansman olanağı verebilmektedir. Aynı zamanda da ithalat, satın alma, yükleme, transfer, akreditif, gibi işlemlerin leasing şirketince yapılabilirliği, leasing'i daha avantajlı yapmaktadır. Amortismana bağlı her çeşit malın leasing yöntemi ile alınabilirliği de, finansal kiralamayı her alanda kullanılabilir yapmaktadır. Son yıllarda bütün dünyaca kabul gören, Türkiye'de de yaygın olarak kullanılan leasing hem taraflara hem de ülkeye ekonomik avantajlar sağlamaktadır (Berk, 2003: 260-261).Avantajları: Kredilendirme prosedürünün bankalara göre daha esnek ve çabuk olması bu prosedürün bankalarda olması gereken kısıtlayıcı unsurlara sahip olmaması, Malın mülkiyet hakkının finansal kiralama şirketlerinde kalması sebebiyle yatırımcılar için teminat ihtiyacı vermesi asgari orana inmesiyle bankaların kredi vermediği şirketler için alternatif olması, Leasing firmasının satın alma/ithalat için tüm işlemleri yapması, İşletmelerin nakit akışlarını düzenli tutmasını sağlayan esnek ve uygun ödeme 
planları sunması, yatırımlarında orta ve uzun vadeli fon ihtiyaçlarının karşılanması, yatırımlara ayıracağı kaynağının işletme sermayesi olarak kullanılması, Diğer finansman yöntemleri ile \%18 KDV öderken, finansal kiralama yolu ile temin ettiği birçok mal için \%1 KDV ödeyerek KDV avantajı sağlaması (Akbulut, 2004: 18-19), Dezavantajları: Leasing'e konu malın kullanım serbestliği, malın satın alınması durumuna kıyasla sınırlıdır. Kiracı malın üzerinde yapmak istediği değişiklikler için önce leasing şirketinden izin almak zorundadır. Kiralama süresinin belli, kira bedellerinin sabit olması enflasyon karşısında korunabilmeyi sağlamaktadır ancak enflasyon değer artışı yatırımcı firmaya yarar sağlayamamaktadır. Yatırımcının seçtiği malı finansal kiralama yapabilmesi için teminat göstermesi gerekmektedir, bu durum da firmanın kredibilitesini düşürmektedir. Kira oluşturan tutarlara yayılmış yüksek faiz yükü vardır (Toroslu, 2000: 121).Kira ödemeleri aksatıldığı takdirde kiracı malı derhal leasing firmasına teslim etmek zorundadır ve zararı ödemekle yükümlüdür (Yıldırım vd., 2006: 367).

\section{BİR MADEN FİRMASINDA ISŞ MAKİNESİ ALIMINDA LEASING FİRMASI SEÇIM PROBLEMINDE AHP VE TOPSIS YÖNTEMLERININ UYGULANMASI}

Bilinçaltı reklama maruz kalan tüketicilerin; inanç ve tutumları, verilen mesaja güvenleri ile satın alma niyetleri verilmek istenen mesajdan etkilenmektedir. Tüketicide satın alma niyeti oluşturabilmek için verilen mesajın tüketicinin inanç ve tutumunda olumlu etki yaratması ve mesaja güvenin artırılması önemlidir.

Çalışmanın uygulama konusu olarak madencilik sektöründe faaliyet gösteren orta ölçekli bir firmanın mermer ocaklarında çalıştırılmak üzere alacağı iş makinesinde tercih ettiği leasing finansmanında leasing firması seçimi ele alınmıştır. Problemin çözüm yöntemi olarak çoklu karar verme yöntemlerinden AHP ve TOPSIS tercih edilmiştir. Uygulamada 2016 yılındaki teklif alınan 3 alternatif leasing firması (L1,L2,L3) arasında en uygun olan seçilmek istenmektedir. Bu seçim için genel müdür ve muhasebe/finans müdürü ile görüşülerek leasing firması seçiminde kullanılacak kriterler belirlenmiştir. 5 adet kriter belirlenmiştir;

Maliyet: Leasing firmasının geri ödeme planında uygulayacağı faiz sonucunda işletme bir maliyete katlanacaktır. Bu maliyet ne kadar düşük olursa işletme için maliyet azalacaktır. Bu kriter işletme için en önemli kriterlerden biridir. Peşinat Tutarı: Leasing firmasının ön ödeme için belirleyeceği tutardır. Bu kriter de işletme için diğer bir önemli kriterdir. Çünkü işletme likit kaynağını bu yatırım için minimum seviyede tutarak farklı yatırımlarda değerlendirmek istemektedir. Peşinat tutarının minimum olması tercih edilmektedir. Firmanın Güvenilirliği: Teklif alınan leasing firmaları Türkiye'nin güvenilir bankalarının leasing kuruluşlarıdır. Ancak burada devreye daha önceki tecrübeler, ilk defa çalışılacak olan firma için referanslar söz konusu olacaktır. Karar vermede leasing firmasının Pazar payı da devreye girecektir. İpotek Tutarı: Leasing firmasının taşınmaz üzerine koyacağı ipotek tutarıdır. Geri ödeme süresince alınacak ipotek meblağı ipoteğin limit ipoteği olması sebebiyle geri ödeme süresine bakılarak tayin edilir. İşlemlerin Sonuçlandırılma Süresi: Satıcı firma ile görüşüp, teklifin sunulup, istenen evraklar teslim edildikten sonra sözleşmenin kurulup, satın alma sürecinin gerçekleştirilmesiyle teslim edilene kadar geçen süredir. Sürenin kısa olması tercih sebebidir.

Uygulama kapsamına alınan leasing firmalarının maliyet, peşinat tutarı ve işlemlerin sonlandırılma süreleri firmalardan istenen 400.000,00 TL değerindeki bir iş makinesi için istenen 48 aylık leasing tekliflerinden elde edilmiştir. Teklifler Tablo 3'te gösterilmektedir. 
Tablo 3. Leasing Teklifleri (Nisan/2016)

\begin{tabular}{|c|c|c|c|c|c|}
\hline \multirow{2}{*}{\multicolumn{2}{|c|}{ L1 FINANSAL KİRALAMA A.Ş. }} & \multicolumn{2}{|c|}{ L2 FİNANSAL KİRALAMA A.Ş. } & \multicolumn{2}{|c|}{ L3 FİNANSAL KİRALAMA A.Ş. } \\
\hline & & Tahmini Ma & sraflar Hariç & Tahmini & Masraflar Hariç \\
\hline Para Birimi & TL & Para Birimi & TL & Para Birimi & TL \\
\hline $\begin{array}{l}\text { Fiyatlama } \quad \text { Baz } \\
\text { Maliyeti }\end{array}$ & $400.000,00$ & \begin{tabular}{|ll}
$\begin{array}{l}\text { Fiyatlama } \\
\text { Maliyeti }\end{array}$ & Baz \\
\end{tabular} & $400.000,00$ & $\begin{array}{ll}\text { Fiyatlama } \\
\text { Maliyeti }\end{array}$ & $400.000,00$ \\
\hline İpotek Tutarı & $160.000,00$ & İpotek Tutarı & $200.000,00$ & İpotek Tutarı & $80.000,00$ \\
\hline & $\% 1$ Kira KDV hariç & & \% 1 Kira KDV hariç & & \% 1 Kira KDV hariç \\
\hline Dönem & DÖNEM 1 AYDA 1 & Dönem & DÖNEM 1 AYDA 1 & Dönem & DÖNEM 1 AYDA 1 \\
\hline Ödeme No & Tutar & Ödeme No & Tutar & Ödeme No & Tutar \\
\hline Peşin Ödeme & $12.044,00$ & Peşin Ödeme & $11.331,00$ & Peşin Ödeme & $11.629,00$ \\
\hline 1. Dönem & $12.044,00$ & 1. Dönem & $11.331,00$ & 1. Dönem & $11.629,00$ \\
\hline 2. Dönem & $12.044,00$ & 2. Dönem & $11.331,00$ & 2. Dönem & $11.629,00$ \\
\hline 3. Dönem & $12.044,00$ & 3. Dönem & $11.331,00$ & 3. Dönem & $11.629,00$ \\
\hline 4. Dönem & $12.044,00$ & 4. Dönem & $11.331,00$ & 4. Dönem & $11.629,00$ \\
\hline 5. Dönem & $12.044,00$ & 5. Dönem & $11.331,00$ & 5. Dönem & $11.629,00$ \\
\hline 6. Dönem & $12.044,00$ & 6. Dönem & $11.331,00$ & 6. Dönem & $11.629,00$ \\
\hline 7. Dönem & $12.044,00$ & 7. Dönem & $11.331,00$ & 7. Dönem & $11.629,00$ \\
\hline 8. Dönem & $12.044,00$ & 8. Dönem & $11.331,00$ & 8. Dönem & $11.629,00$ \\
\hline 9. Dönem & $12.044,00$ & 9. Dönem & $11.331,00$ & 9. Dönem & $11.629,00$ \\
\hline 10. Dönem & $12.044,00$ & 10. Dönem & $11.331,00$ & 10. Dönem & $11.629,00$ \\
\hline 11. Dönem & $12.044,00$ & 11. Dönem & $11.331,00$ & 11. Dönem & $11.629,00$ \\
\hline 12. Dönem & $12.044,00$ & 12. Dönem & $11.331,00$ & 12. Dönem & $11.629,00$ \\
\hline 13. Dönem & $12.044,00$ & 13. Dönem & $11.331,00$ & 13. Dönem & $11.629,00$ \\
\hline 14. Dönem & $12.044,00$ & 14. Dönem & $11.331,00$ & 14. Dönem & $11.629,00$ \\
\hline 15. Dönem & $12.044,00$ & 15. Dönem & $11.331,00$ & 15. Dönem & $11.629,00$ \\
\hline 16. Dönem & $12.044,00$ & 16. Dönem & $11.331,00$ & 16. Dönem & $11.629,00$ \\
\hline 17. Dönem & $12.044,00$ & 17. Dönem & $11.331,00$ & 17. Dönem & $11.629,00$ \\
\hline 18. Dönem & $12.044,00$ & 18. Dönem & $11.331,00$ & 18. Dönem & $11.629,00$ \\
\hline 19. Dönem & $12.044,00$ & 19. Dönem & $11.331,00$ & 19. Dönem & $11.629,00$ \\
\hline 20. Dönem & $12.044,00$ & 20. Dönem & $11.331,00$ & 20. Dönem & $11.629,00$ \\
\hline 21. Dönem & $12.044,00$ & 21. Dönem & $11.331,00$ & 21. Dönem & $11.629,00$ \\
\hline 22. Dönem & $12.044,00$ & 22. Dönem & $11.331,00$ & 22. Dönem & $11.629,00$ \\
\hline 23. Dönem & $12.044,00$ & 23. Dönem & $11.331,00$ & 23. Dönem & $11.629,00$ \\
\hline 24. Dönem & $12.044,00$ & 24. Dönem & $11.331,00$ & 24. Dönem & $11.629,00$ \\
\hline 25. Dönem & $12.044,00$ & 25. Dönem & $11.331,00$ & 25. Dönem & $11.629,00$ \\
\hline 26. Dönem & $12.044,00$ & 26. Dönem & $11.331,00$ & 26. Dönem & $11.629,00$ \\
\hline 27. Dönem & $12.044,00$ & 27. Dönem & $11.331,00$ & 27. Dönem & $11.629,00$ \\
\hline 28. Dönem & $12.044,00$ & 28. Dönem & $11.331,00$ & 28. Dönem & $11.629,00$ \\
\hline 29. Dönem & $12.044,00$ & 29. Dönem & $11.331,00$ & 29. Dönem & $11.629,00$ \\
\hline 30. Dönem & $12.044,00$ & 30. Dönem & $11.331,00$ & 30. Dönem & $11.629,00$ \\
\hline 31. Dönem & $12.044,00$ & 31. Dönem & $11.331,00$ & 31. Dönem & $11.629,00$ \\
\hline 32. Dönem & $12.044,00$ & 32. Dönem & $11.331,00$ & 32. Dönem & $11.629,00$ \\
\hline 33. Dönem & $12.044,00$ & 33. Dönem & $11.331,00$ & 33. Dönem & $11.629,00$ \\
\hline 34. Dönem & $12.044,00$ & 34. Dönem & $11.331,00$ & 34. Dönem & $11.629,00$ \\
\hline 35. Dönem & $12.044,00$ & 35. Dönem & $11.331,00$ & 35. Dönem & $11.629,00$ \\
\hline 36. Dönem & $12.044,00$ & 36. Dönem & $11.331,00$ & 36. Dönem & $11.629,00$ \\
\hline 37. Dönem & $12.044,00$ & 37. Dönem & $11.331,00$ & 37. Dönem & $11.629,00$ \\
\hline 38. Dönem & $12.044,00$ & 38. Dönem & \begin{tabular}{|l|}
$11.331,00$ \\
\end{tabular} & 38. Dönem & \begin{tabular}{|l|}
$11.629,00$ \\
\end{tabular} \\
\hline 39. Dönem & $12.044,00$ & 39. Dönem & $11.331,00$ & 39. Dönem & $11.629,00$ \\
\hline 40. Dönem & $12.044,00$ & 40. Dönem & $11.331,00$ & 40. Dönem & $11.629,00$ \\
\hline 41. Dönem & $12.044,00$ & 41. Dönem & \begin{tabular}{|l|}
$11.331,00$ \\
\end{tabular} & 41. Dönem & $11.629,00$ \\
\hline 42. Dönem & $12.044,00$ & 42. Dönem & $11.331,00$ & 42. Dönem & $11.629,00$ \\
\hline 43. Dönem & $12.044,00$ & 43. Dönem & $11.331,00$ & 43. Dönem & $11.629,00$ \\
\hline 44. Dönem & $12.044,00$ & 44. Dönem & $11.331,00$ & 44. Dönem & $11.629,00$ \\
\hline 45. Dönem & $12.044,00$ & 45. Dönem & $11.331,00$ & 45. Dönem & $11.629,00$ \\
\hline 46. Dönem & $12.044,00$ & 46. Dönem & $11.331,00$ & 46. Dönem & $11.629,00$ \\
\hline 47. Dönem & $12.044,00$ & 47. Dönem & $11.331,00$ & 47. Dönem & $11.629,00$ \\
\hline Toplam & $578.112,00$ & Toplam & $543.888,00$ & Toplam & $558.192,00$ \\
\hline
\end{tabular}




\subsection{AHP Yöntemi ile Çözüm}

Adım 1: Karar verme problemi tanımlanır. 3 karar noktası ve 5 değerlendirme faktörü bulunmaktadır. Karar probleminin hiyerarşik yapısı aşağıdaki gibidir.

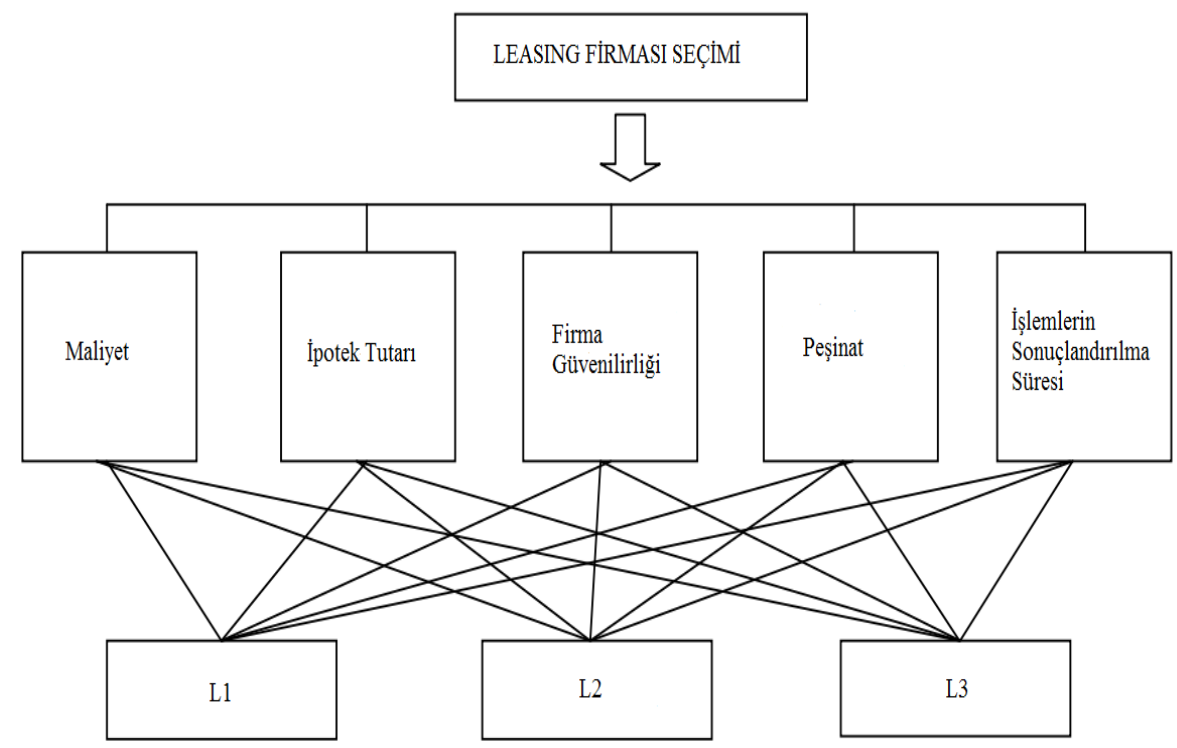

Şekil 2. Leasing Firması Seçiminde Oluşturulan Hiyerarşik Yapı

Adım 2: Faktörler arası ikili karşılaştırma matrisi oluşturulur. İkili karşılaştırmalar matrisi Genel Müdür ve Muhasebe/Finans Müdürü tarafından birlikte yapılan çalışma ile oluşturulmuştur. Bu karşılaştırılmalar yapılırken Saaty tarafından belirlenen ve Tablo 1'de gösterilen 9 ölçekli önem skalası kullanılmıştır. İkili karşılaştırmalar matrisi ise Tablo 4'te gösterilmiştir.

Tablo 4. İkili Karşılaştırmalar Matrisi

\begin{tabular}{|l|c|c|c|c|c|}
\hline & Maliyet & $\begin{array}{c}\text { İpotek } \\
\text { Tutarı }\end{array}$ & $\begin{array}{c}\text { Firma } \\
\text { Güvenilirliği }\end{array}$ & Peşinat & $\begin{array}{c}\text { İşlemin Sonlandırılma } \\
\text { Süresi }\end{array}$ \\
\hline Maliyet & 1,0000 & 3,0000 & 5,0000 & 7,0000 & 9,0000 \\
\hline İpotek Tutarı & 0,3333 & 1,0000 & 3,0000 & 5,0000 & 7,0000 \\
\hline Firma Güvenilirliği & 0,2000 & 0,3333 & 1,0000 & 3,0000 & 5,0000 \\
\hline Peşinat & 0,1429 & 0,2000 & 0,3333 & 1,0000 & 3,0000 \\
\hline İşlemin Son. Süresi & 0,1111 & 0,1429 & 0,2000 & 0,3333 & 1,0000 \\
\hline
\end{tabular}

Adım 3: İkili karşılaştırmalar matrisi oluşturulduktan sonra kriter ağırlıkları tespit edilir. Kriterlerin ağırlıkları ikili karşılaştırma matrisindeki her bir sütun değerinin ayrı ayrı ilgili sütun toplamı değerine bölünmesi ile normalleştirilmiş matris elde edilmiştir. Tablo 5 'te gösterilen İkili karşılaştırma matrisinden yola çııılarak her bir sıra toplamının ortalaması alınarak kriter ağırlıkları hesaplanmıştır ve Tablo 6' da gösterilmiştir. 
Tablo 5. İkili Karş1laştırmalar Matrisi

\begin{tabular}{|l|c|c|c|c|c|}
\hline & Maliyet & $\begin{array}{c}\text { İpotek } \\
\text { Tutarı }\end{array}$ & $\begin{array}{c}\text { Firma } \\
\text { Güvenilirliği }\end{array}$ & Peşinat & $\begin{array}{c}\text { İşlemin Sonlandırılma } \\
\text { Süresi }\end{array}$ \\
\hline Maliyet & 1,0000 & 3,0000 & 5,0000 & 7,0000 & 9,0000 \\
\hline İpotek Tutarı & 0,3333 & 1,0000 & 3,0000 & 5,0000 & 7,0000 \\
\hline Firma Güvenilirliği & 0,2000 & 0,3333 & 1,0000 & 3,0000 & 5,0000 \\
\hline Peşinat & 0,1429 & 0,2000 & 0,3333 & 1,0000 & 3,0000 \\
\hline İşlemin Son. Süresi & 0,1111 & 0,1429 & 0,2000 & 0,3333 & 1,0000 \\
\hline TOPLAM & 1,7873 & 4,6762 & 9,5333 & 16,3333 & 25,0000 \\
\hline
\end{tabular}

Tablo 6. Normalleştirilmiş Matris ve Kriter Ağırlıkları

\begin{tabular}{|l|c|c|c|c|c|c|c|}
\hline & Maliyet & $\begin{array}{c}\text { Ípotek } \\
\text { Tutarı }\end{array}$ & $\begin{array}{c}\text { Firma } \\
\text { Güvenilirliği }\end{array}$ & Peşinat & $\begin{array}{c}\text { İşlemin } \\
\text { Sonlandırılma } \\
\text { Süresi }\end{array}$ & Toplam & Ağırlık \\
\hline Maliyet & 0,5595 & 0,6415 & 0,5245 & 0,4286 & 0,3600 & 2,5141 & 0,50 \\
\hline Ipotek Tutarı & 0,1865 & 0,2138 & 0,3147 & 0,3061 & 0,2800 & 1,3012 & 0,26 \\
\hline Firma Güvenilirliği & 0,1119 & 0,0713 & 0,1049 & 0,1837 & 0,2000 & 0,6718 & 0,13 \\
\hline Peşinat & 0,0799 & 0,0428 & 0,0350 & 0,0612 & 0,1200 & 0,3389 & 0,07 \\
\hline İslemin Son. Süresi & 0,0622 & 0,0305 & 0,0210 & 0,0204 & 0,0400 & 0,1741 & 0,03 \\
\hline
\end{tabular}

Adım 4: Faktör kıyaslamalarındaki Tutarlılık ölçülür. Kriterler arasında karşılaştırma yapılırken tutarlı davranılıp davranılmadığı ölçülür. Bunun için tutarlılık oranı hesaplanır. İkili karşılaştırma matrisinin her sütunu ilgili ağırlıkla çarpılır yeni bir sütun oluşturulur. Birinci ağırlık değeri birinci sütun değeri ile çarpılarak devam ederek $D$ matrisi oluşturulur. Sonra formül (17) ile temel değerler $(E)$ vektörü elde edilir. $E$ matrisindeki değerlerin aritmetik ortalaması alınarak $(\lambda)$ hesaplanır. $(\lambda)$ hesaplandıktan sonra da formül (19) ile tutarlılık göstergesi hesabı yapılır. Son olarak da formül (20) ile tutarlılık oranı hesaplanır. İşlemler Tablo 7'de gösterilmiştir.

Tablo 7. Değerler Matrisi

\begin{tabular}{|c|c|c|c|c|c|c|c|}
\hline & Maliyet & $\begin{array}{l}\text { İpotek } \\
\text { Tutarı } \\
\end{array}$ & $\begin{array}{c}\text { Firma } \\
\text { Güvenilirliği } \\
\end{array}$ & Peşinat & $\begin{array}{c}\text { İşlemin } \\
\text { Son. Süresi }\end{array}$ & Toplam & $\begin{array}{l}\text { Temel } \\
\text { Değer }\end{array}$ \\
\hline Maliyet & 0,5028 & 0,7807 & 0,6718 & 0,4744 & 0,3134 & 2,7431 & 5,46 \\
\hline İpotek Tutarı & 0,1676 & 0,2602 & 0,4031 & 0,3389 & 0,2437 & 1,4135 & 5,43 \\
\hline Firma Güvenilirliği & 0,1006 & 0,0867 & 0,1344 & 0,2033 & 0,1741 & 0,6991 & 5,20 \\
\hline Peşinat & 0,0718 & 0,0520 & 0,0448 & 0,0678 & 0,1045 & 0,3409 & 5,03 \\
\hline İşlemin Son. Süresi & 0,0559 & 0,0372 & 0,0269 & 0,0226 & 0,0348 & 0,1773 & 5,09 \\
\hline \multicolumn{7}{|l|}{ Toplam } & 26,21 \\
\hline \multicolumn{7}{|l|}{$\lambda$} & 5,24 \\
\hline \multicolumn{7}{|l|}{ CI } & 0,06 \\
\hline \multicolumn{7}{|l|}{$\mathbf{R I}$} & 1,12 \\
\hline \multicolumn{7}{|l|}{$\overline{\text { CR }}$} & $0,05^{*}$ \\
\hline
\end{tabular}

${ }^{*} \mathrm{CR}<0,10$ olması matrislerin tutarlı olduğunu gösterir.

Adım 5: Her bir değerlendirme faktörü için karar noktalarının önem dağılımları hesaplanır. Yine burada da daha önce olduğu gibi ikili karşılaştırma matrisleri Genel Müdür ve Muhasebe/Finans Müdürü tarafından birlikte yapılan çalışma ile oluşturulmuştur. Bu hesaplamalarda Tablo 3'teki önem tanımları kullanılmıştır. Her bir karşılaştırma için 
tutarlılık ölçülmüştür. 1.Değerlendirme faktörü için karar noktaları önem dağglımı Tablo 8'de verilmiştir.

Tablo 8. Maliyet Faktörünün İkili Karşılaştırılması

\begin{tabular}{|l|c|c|c|}
\hline & L1 & L2 & L3 \\
\hline L1 & 1,0000 & 0,1250 & 0,1666 \\
\hline L2 & 8,0000 & 1,0000 & 2,0000 \\
\hline L3 & 6,0000 & 0,5000 & 1,0000 \\
\hline & 15,0000 & 1,6250 & 3,1666 \\
\hline
\end{tabular}

Önem tanımları yapıldıktan sonra karşılaştırma matrisinin sütun toplam değerleri elde edilmiştir. Tutarlılık hesaplaması:

Tablo 9. Maliyet Faktörü Normalleştirilmiş Matris ve Ağırlıkları

\begin{tabular}{|l|c|c|c|c|c|}
\hline & L1 & L2 & L3 & Toplam & A ğırlık \\
\hline L1 & 0,0667 & 0,0769 & 0,0526 & 0,1962 & 0,07 \\
\hline L2 & 0,5333 & 0,6154 & 0,6316 & 1,7803 & 0,59 \\
\hline L3 & 0,4000 & 0,3077 & 0,3158 & 1,0235 & 0,34 \\
\hline
\end{tabular}

Tablo 10. Maliyet Faktörü Değerler Matrisi

\begin{tabular}{|c|c|c|c|c|c|}
\hline & L1 & L2 & L3 & Toplam & Temel Değer \\
\hline L1 & 0,0654 & 0,0742 & 0,0568 & 0,1964 & 3,00 \\
\hline L2 & 0,5232 & 0,5934 & 0,6823 & 1,7990 & 3,03 \\
\hline L3 & 0,3924 & 0,2967 & 0,3412 & 1,0303 & 3,02 \\
\hline \multicolumn{5}{|c|}{ Toplam } & 9,05 \\
\hline \multicolumn{5}{|l|}{$\lambda$} & 3,02 \\
\hline \multicolumn{5}{|l|}{ CI } & 0,01 \\
\hline \multicolumn{5}{|l|}{ RI } & 0,58 \\
\hline \multicolumn{5}{|c|}{ CR } & $0,02^{*}$ \\
\hline
\end{tabular}

${ }^{*} \mathrm{CR}<0,10$ olması tutarlı olduğunu gösterir.

1. Değerlendirme faktörü açısından karar noktalarının önem dağılımları için $S_{1}$ sütun vektörünü hesaplarken öncelikle karşılaştırma matrisinin sütunlarındaki sütun toplamlarına bölünmüş, satır toplamları bulunmuş ve değerlerin aritmetik ortalamaları alınmıştır. Bu vektörden 1. değerlendirme faktörü açısından L1 \%7, L2 \%59, L3 \%34 öneme sahiptir. Aynı şekilde diğer değerlendirme faktörleri için karar noktalarının önem dağılımları aşağıdaki gibi hesaplanmıştır. 2. Değerlendirme faktörü için karar noktalarının önem dağılımı Tablo 11 'de verilmiştir.

Tablo 11. İpotek Tutarı Faktörünün İkili Karşılaştırılması

\begin{tabular}{|l|c|c|c|}
\hline & L1 & L2 & L3 \\
\hline L1 & 1,0000 & 3,0000 & 0,1666 \\
\hline L2 & 0,3333 & 1,0000 & 0,1250 \\
\hline L3 & 6,0000 & 8,0000 & 1,0000 \\
\hline & 7,3333 & 12,0000 & 1,2916 \\
\hline
\end{tabular}

Önem tanımları yapıldıktan sonra karşılaştırma matrisinin sütun toplam değerleri elde edilmiştir. Tutarlılık hesaplaması Tablo 12'de verilmiştir. 
Tablo 12. İpotek Faktörü Normalleştirilmiş Matris ve Ağırlıkları

\begin{tabular}{|l|c|c|c|c|c|}
\hline & L1 & L2 & L3 & Toplam & A ğırlık \\
\hline L1 & 0,1364 & 0,2500 & 0,1290 & 0,5154 & 0,17 \\
\hline L2 & 0,0455 & 0,0833 & 0,0968 & 0,2256 & 0,08 \\
\hline L3 & 0,8182 & 0,6667 & 0,7742 & 2,2591 & 0,75 \\
\hline
\end{tabular}

Tablo 13. İpotek Faktörü Değerler Matrisi

\begin{tabular}{|l|c|c|c|c|c|}
\hline & L1 & L2 & L3 & Toplam & Temel Değer \\
\hline L1 & 0,1718 & 0,2256 & 0,1255 & 0,5228 & 3,04 \\
\hline L2 & 0,0573 & 0,0752 & 0,0941 & 0,2266 & 3,01 \\
\hline L3 & 1,0307 & 0,6015 & 0,7530 & 2,3852 & 3,17 \\
\hline Toplam & & 9,22 \\
\hline$\lambda$ & CI & 3,07 \\
\hline RI & & 0,04 \\
\hline CR
\end{tabular}

${ }^{*} \mathrm{C} R<0,10$ olması tutarlı olduğunu gösterir.

$\mathrm{Bu}$ vektörden 2. değerlendirme faktörü açısından L1 \%17, L2 \%8, L3 \%75 öneme sahip olduğu söylenebilir.3.Değerlendirme faktörü için karar noktalarının önem dağılımı Tablo 14 'te verilmiştir.

Tablo 14. Firma Güvenilirliği Faktörünün İkili Karşılaştırılması

\begin{tabular}{|l|c|c|c|}
\hline & L1 & L2 & L3 \\
\hline L1 & 1,0000 & 6,0000 & 3,0000 \\
\hline L2 & 0,1666 & 1,0000 & 0,2000 \\
\hline L3 & 0,3333 & 5,0000 & 1,0000 \\
\hline & 1,4999 & 12,0000 & 4,2000 \\
\hline
\end{tabular}

Önem tanımları yapıldıktan sonra karşılaştırma matrisinin sütun toplam değerleri elde edilmiştir. Tutarlılık hesaplama Tablo 15 ve 16 'da verilmiştir.

Tablo 15. Firma Güven. Faktörü Normalleştirilmiş Matris ve Ağırlıkları

\begin{tabular}{|l|c|c|c|c|c|}
\hline & L1 & L2 & L3 & Toplam & Ăgırlık \\
\hline L1 & 0,6316 & 0,4000 & 0,7143 & 1,7459 & 0,58 \\
\hline L2 & 0,1579 & 0,1000 & 0,0476 & 0,3055 & 0,10 \\
\hline L3 & 0,2105 & 0,5000 & 0,2381 & 0,9486 & 0,32 \\
\hline
\end{tabular}

Tablo 16. Firma Güven. Faktörü Değerler Matrisi

\begin{tabular}{|l|c|c|c|c|c|}
\hline & L1 & L2 & L3 & Toplam & Temel Değer \\
\hline L1 & 0,6270 & 0,4841 & 0,8770 & 1,9880 & 3,17 \\
\hline L2 & 0,1045 & 0,0807 & 0,0585 & 0,2436 & 3,02 \\
\hline L3 & 0,2090 & 0,4034 & 0,2923 & 0,9047 & 3,09 \\
\hline Toplam & & 9,28 \\
\hline$\lambda$ & CI & & 3,09 \\
\hline RI & & 0,05 \\
\hline CR
\end{tabular}

${ }^{*} \mathrm{CR}<0,10$ olması tutarlı olduğunu gösterir. 
$\mathrm{Bu}$ vektörden 3. değerlendirme faktörü açısından L1 \%63, L2 \%8, L3 \%29 öneme sahip olduğu söylenebilir.4.Değerlendirme faktörü için karar noktalarının önem dağılımı Tablo 17 'de verilmiştir.

Tablo 17. Peşinat Faktörünün İkili Karşılaştırılması

\begin{tabular}{|l|c|c|c|}
\hline & L1 & L2 & L3 \\
\hline L1 & 1,0000 & 0,2500 & 0,3333 \\
\hline L2 & 4,0000 & 1,0000 & 3,0000 \\
\hline L3 & 3,0000 & 0,3333 & 1,0000 \\
\hline & 8,0000 & 1,5833 & 4,3333 \\
\hline
\end{tabular}

Önem tanımları yapıldıktan sonra karşılaştırma matrisinin sütun toplam değerleri elde edilmiştir. Tutarlılık hesaplama Tablo 18 ve 19'da verilmiştir.

Tablo 18. Peşinat Faktörü Normalleştirilmiş Matris ve Ağırlıkları

\begin{tabular}{|l|c|c|c|c|c|}
\hline & L1 & L2 & L3 & Toplam & A ğırlık \\
\hline L1 & 0,1250 & 0,1579 & 0,0769 & 0,3598 & 0,12 \\
\hline L2 & 0,5000 & 0,6316 & 0,6923 & 1,8239 & 0,61 \\
\hline L3 & 0,3750 & 0,2105 & 0,2308 & 0,8163 & 0,27 \\
\hline
\end{tabular}

Tablo 19. Peşinat Faktörü Değerler Matrisi

\begin{tabular}{|l|c|c|c|c|c|}
\hline & L1 & L2 & L3 & Toplam & Temel Değer \\
\hline L1 & 0,1199 & 0,1520 & 0,0907 & 0,3626 & 3,02 \\
\hline L2 & 0,4798 & 0,6080 & 0,8163 & 1,9040 & 3,13 \\
\hline L3 & 0,3598 & 0,2026 & 0,2721 & 0,8345 & 3,07 \\
\hline Toplam & 9,22 \\
\hline$\lambda$ & CI & 3,07 \\
\hline RI & & 0,04 \\
\hline CR
\end{tabular}

${ }^{*} \mathrm{CR}<0,10$ olması tutarlı olduğunu gösterir.

$\mathrm{Bu}$ vektörden 4. değerlendirme faktörü açısından L1 \% 12, L2 \%61, L3 \%27 öneme sahip olduğu söylenebilir. 5. Değerlendirme faktörü için karar noktalarının önem dağılımı Tablo 20 'de verilmiştir.

Tablo 20. İşlemlerin Sonuçlandırılma Süresi Faktörünün İkili Karşılaştırılması

\begin{tabular}{|l|c|c|c|}
\hline & L1 & L2 & L3 \\
\hline L1 & 1,0000 & 4,0000 & 2,0000 \\
\hline L2 & 0,2500 & 1,0000 & 0,5000 \\
\hline L3 & 0,5000 & 2,0000 & 1,0000 \\
\hline & 1,7500 & 7,0000 & 3,5000 \\
\hline
\end{tabular}

Önem tanımları yapıldıktan sonra karşılaştırma matrisinin sütun toplam değerleri elde edilmiştir. Tutarlılık hesaplama Tablo 21 ve 22 'de verilmiştir. 
Tablo 21. İş. Son. Faktörü Normalleştirilmiş Matris ve Ağırlıkları

\begin{tabular}{|l|c|c|c|c|c|}
\hline & L1 & L2 & L3 & Toplam & A ğırlık \\
\hline L1 & 0,5714 & 0,5714 & 0,5714 & 1,7143 & 0,57 \\
\hline L2 & 0,1429 & 0,1429 & 0,1429 & 0,4286 & 0,14 \\
\hline L3 & 0,2857 & 0,2857 & 0,2857 & 0,8571 & 0,29 \\
\hline
\end{tabular}

Tablo 22. İş. Son. Faktörü Değerler Matrisi

\begin{tabular}{|l|c|c|c|c|c|}
\hline & L1 & L2 & L3 & Toplam & Temel Değer \\
\hline L1 & 0,5714 & 0,5714 & 0,5714 & 1,7143 & 3,00 \\
\hline L2 & 0,1429 & 0,1429 & 0,1429 & 0,4286 & 3,00 \\
\hline L3 & 0,2857 & 0,2857 & 0,2857 & 0,8571 & 3,00 \\
\hline Toplam & & 9,00 \\
\hline$\lambda$ & CI & 3,00 \\
\hline RI & & 0,00 \\
\hline CR
\end{tabular}

${ }^{*} \mathrm{C} R<0,10$ olması tutarlı olduğunu gösterir.

Bu vektörden 5. değerlendirme faktörü açısından L1 \% 57, L2 \%14, L3 \%29 öneme sahip olduğu söylenebilir.

Tablo 23. Önem Ağırlıkları

$$
\left|\begin{array}{lllll}
0,07 & 0,17 & 0,63 & 0,12 & 0,57 \\
0,59 & 0,08 & 0,08 & 0,61 & 0,14 \\
0,34 & 0,75 & 0,29 & 0,27 & 0,29
\end{array}\right| \times\left|\begin{array}{l}
0,5 \\
0,26 \\
0,13 \\
0,07 \\
0,03
\end{array}\right|=\left|\begin{array}{l}
0,18 \\
0,37 \\
0,43
\end{array}\right|
$$

Elde edilen sütun vektöründeki 0,18 1. Karar noktasının L1 önem seviyesini, 0,37 2. Karar noktasının L2 önem seviyesini, 0,43 3. Karar noktası L3 önem seviyesini göstermektedir. Diğer bir ifadeyle karar noktalarının önem dizilişi L3,L2,L1 şeklinde olacaktır.

\subsection{TOPSIS Yöntemi İle Çözüm: TOPSIS Yöntemi Uygulama Aşamaları}

Adım 1: Karar Matrisinin (A) Oluşturulması

Firmalar ve değerlendirme faktörlerinden oluşan Karar Matrisi (A) Tablo 24'te verilmiştir.

Tablo 24. Karar Matrisi (A)

\begin{tabular}{|l|c|c|c|c|c|}
\hline Firmalar & Maliyet & İpotek Tutarı & Firma Güvenilirliği & Peşinat & İşlemlerin Sonuç. Süresi \\
\hline L1 & $178.112,00$ & $160.000,00$ & 95 & $12.044,00$ & 3 \\
\hline L2 & $134.888,00$ & $200.000,00$ & 80 & $11.331,00$ & 7 \\
\hline L3 & $158.192,00$ & $80.000,00$ & 90 & $11.629,00$ & 5 \\
\hline
\end{tabular}

Adım 2: Standart Karar Matrisinin (R) Oluşturulması

Karar matrisinden formül (2) yardımıyla hesaplanan Standart Karar Matrisi aşağıdaki Tablo 25 'te gösterilmiştir. 
Tablo 25. Standart Karar Matrisi (R)

\begin{tabular}{|l|c|c|c|c|c|}
\hline Firmalar & Maliyet & İpotek Tutar1 & Firma Güvenilirliği & Peşinat & İşlemlerin Sonuç. Süresi \\
\hline L1 & 0,65 & 0,60 & 0,62 & 0,60 & 0,33 \\
\hline L2 & 0,49 & 0,75 & 0,52 & 0,56 & 0,77 \\
\hline L3 & 0,58 & 0,30 & 0,59 & 0,58 & 0,55 \\
\hline
\end{tabular}

Adım 3: Ağırlıklı Standart Matrisinin (V) Oluşturulması

Ağırlıklı standart karar matrisi oluşturulurken AHP ile hesaplanan değerlendirme faktörlerine ilişkin ağırlık değerleri kullanılır. Ağırlıklar Tablo 26'dadır.

Tablo 26. Değerlendirme Kriterlerinin Ağırlık Değerleri

\begin{tabular}{|l|c|c|c|c|c|}
\hline & Maliyet & İpotek Tutarı & Firma Güvenilirliği & Peşinat & $\begin{array}{c}\text { İşlemlerin Sonuç. } \\
\text { Süresi }\end{array}$ \\
\hline Kriter Ağırlıkları & 0,50 & 0,26 & 0,13 & 0,07 & 0,03 \\
\hline
\end{tabular}

Standart karar matrisi ve $\left(\sum_{j=1}^{n} w_{j}=1\right) \mathrm{R}$ matrisi formülü kullanılarak ağırlıklı standart karar matrisi (V) oluşturulur.

Tablo 27. Ağırlıklı Standart Karar Matrisi (V)

\begin{tabular}{|l|c|c|c|c|c|}
\hline Firmalar & Maliyet & İpotek Tutarı & Firma Güvenilirliği & Peşinat & İşlemlerin Sonuç. Süresi \\
\hline L1 & 0,325 & 0,155 & 0,081 & 0,042 & 0,010 \\
\hline L2 & 0,246 & 0,194 & 0,068 & 0,039 & 0,023 \\
\hline L3 & 0,289 & 0,078 & 0,076 & 0,040 & 0,016 \\
\hline
\end{tabular}

Adım 4: Firma güvenilirliği dışında diğer kriterler minimizasyon yönlü olduğu için pozitif çözüm kümesi için en küçük değerler, negatif çözüm kümesi için en büyük değerler seçilmiştir.

$$
\begin{aligned}
& A^{+}=\{0,246 ; 0,078 ; 0,081 ; 0,039 ; 0,010\} \\
& A^{-}=\{0,325 ; 0,194 ; 0,068 ; 0,042 ; 0,023\}
\end{aligned}
$$

Adım 5: Alternatifler Arasındaki Mesafe Ölçülerinin Hesaplanması

Formül 7 ve 8 yardımıla uzaklıklar; $S^{+}{ }_{1}=0.112, S^{+}{ }_{2}=0.118, S^{+}{ }_{3}=0.046, S_{-1}^{-}=0.043, S_{-2}=0.080$ ve $S_{3}=0.123$ olarak hesaplanmıştır.

Adım 6: İdeal Çözüme Göreli Yakınlığın Hesaplanması

Formül (9) ile yakınlık katsayıları; $\mathrm{C}^{+}{ }_{1}=0.278, \mathrm{C}^{+}{ }_{2}=0.403$ ve $\mathrm{C}^{+}{ }_{3}=0.728$ olarak hesaplanmıştır.

Sıralama önceliğini $C$ değeri en yüksek olan alternatif almaktadır. Karar noktalarının önem sıralaması L3, L2, L1 şeklinde olacaktır.

\section{SONUÇ}

Alternatif finansman araçlarının günümüzdeki yeri ve önemi tartışılamaz bir konudur. Leasing'de tercih yapılırken en önemli faktörlerden birisi maliyettir. Ancak değerlendirme maliyeti yanı sıra; ipotek tutarı, firma güvenilirliği, peşinat tutarı ve işlemlerin sonuçlandırılma süresi gibi kriterlerde etkili olmaktadır. Bu çalışmada da maden sektöründe 
faaliyet gösteren orta ölçekli bir işletmenin mermer ocaklarında çalıştırılmak üzere alacağı bir iş makinesinde tercih edebileceği leasing firması seçimi çok kriterli karar verme yöntemlerinden AHP ve TOPSIS yöntemleri ile değerlendirilerek sonuçları karşılaştırılmıştır. $\mathrm{Bu}$ bağlamda 3 ayrı leasing firmasından teklif alınmış ve belirlenen 5 kriter de çalışmanın kısıtları olarak belirlenmiştir.

Kullanılan kriterlerin ağırlıkları AHP yöntemi ile belirlenmiştir. Kriter ağırlıklarında en önemli kriter maliyet olmakla birlikte ikinci sırada ipotek tutarı ve üçüncü sırada da firma güvenilirliği gelmektedir. Bu sonuçlar de daha az maliyet ve ipotek tutarının yanı sıra tercih edilecek firmanın güvenilirliğinin de önemli olduğunu göstermektedir. AHP yöntemi ile hiyerarşik yapı oluşturularak karar vericiye problemi tanımlama için kolaylık sağlamaktadır. İkili karşılaştırma matrisi normalize edilerek her bir kriterin ağırlıkları hesaplanmıştır. AHP yöntemi ile elde edilen kriter ağırlıkları aynı zamanda TOPSIS yönteminde de kullanılarak değerlendirme yapılmıştır. Değerlendirme sonucunda AHP ve TOPSIS yöntemlerinin her ikisinde de sıralama aynı şekilde oluşmuştur. Elde edilen sonuçlar doğrultusunda işletmeye L3 leasing firmasını tercih etmesi tavsiye edilmiştir. Karar vericiler elde edilen sıralamayı makul bulmuştur.

TOPSIS ve AHP yöntemleri çözüm adımları açısından birbirinden tamamen farklıdır. AHP'de faktör ağırlıkları, TOPSIS'te ise hesaplanan ağırlıklara göre hesaplama yapılmıştır. Fakat bu farklılığa rağmen iki yöntem alternatiflerin seçilme olasılıkları açısından tutarlı sonuç vermiştir. Ağırlıklandırma aşamasında TOPSIS, ağırlıklar hesaplandıktan sonra yapılan hesaplarda da AHP zayıf kalmaktadır. AHP TOPSIS'e göre daha karmaşık hesaplamalar gerektirmektedir. AHP'de kriter ve alternatifler için ikili karşılaştırmalar yapılması gerekirken TOPSIS'te buna ihtiyaç duyulmamaktadır. TOPSIS'te pozitif ve negatif ideal çözüme olan uzaklığa göre alternatifler sıralanırken $\mathrm{AHP}^{\prime}$ de ikili karşılaştırmalara dayalı yapılmaktadır. Her iki yöntem de sözel değişkenlere izin vermektedir.

Sonuç olarak Leasing firması seçiminde bu yöntemlerin uygulanabilirliği konusunda olumlu bir uygulama ortaya konmuştur. Yöntemler sonucunda ilk sırada yer alan alternatifin nispeten üstünlük sağlayan alternatif olduğu görülmüştür. Bundan sonraki çalışmalarda çoklu karar verme teknikleri finansman kararlarında kullanılabileceği görülmektedir.

\section{KAYNAKÇA}

Akbulut, D. (2004, Ekim). Açılış Konuşması - Görüşme Tutanağı, Finansal Kiralama Hukuku Sempozyumu, Düzenleyen: Finansal Kiralama Derneği (FIDER) \& Galatasaray Üniversitesi, İstanbul, 11-31.

Akgüç, Ö. (1998). Finansal Yönetim, Yenilenmiş 7. Baskı, İstanbul: Avcıol Basım Yayın.

Ballı, S. ve Korukoğlu, S. (2009). Operating System Selection Using Fuzzy AHP and TOPSIS Methods, Mathematical \& Computational Applications,14(2), 119-130.

Berk, N. (2003). Finansal Yönetim, 7. Baskı, İstanbul: Türkmen Kitabevi.

Ceylan, A. (2003). Finansal Teknikler, 5. Baskı, Bursa: Etkin Kitabevi Yayınları. 
Çondur, F., Evlimoğlu, U. ve Bozdağlıŏlu, Y. (2008). Finansal Yenilikler Kapsamında Leasing'in KOBİ'lerde Kullanılmasına İlişkin Bir Araştırma, Ekonomik ve Sosyal Araştırmalar Dergisi, 4(2), 1-26.

Dağdeviren, M. ve Eren, T. (2001). Tedarikçi Firma Seçiminde Analitik Hiyerarşi Prosesi ve 0-1 Hedef Programlama Yöntemlerinin Kullanılması, Gazi Üniversitesi Mühendislik Fakültesi Dergisi, 16(2), 41-52.

Dumanoğlu, S. ve Ergül N. (2010). İMKB'de İşlem Gören Teknoloji Şirketlerinin Mali Performans Ölçümü, Muhasebe ve Finansman Dergisi, 48, 101-111.

Dündar, S. (2008). Ders Seçiminde Analitik Hiyerarşi Proses Uygulaması, Süleyman Demirel Üniversitesi İ.I.B.F. Dergisi, 13(2), 71-86.

Eleren, A. ve Karagül, M. (2008). 1986 - 2006 Türkiye Ekonomisinin Performans Değerlendirilmesi, Celal Bayar Üniversitesi İ.İ.B.F. Yönetim ve Ekonomi, 15(1),1-14.

Erdoğmuş, Ş. (2003). Karar Kuramı ve Analitik Serim Süreci (AHP) Ders Notları, Fotokopiyle Çoğaltma, Tokat O.G.Ü. Fen Edebiyat Fakültesi.

Ertuğrul, İ. (2003, Mayıs). İşyeri Düzen Tasarımına Bir Analitik Hiyerarşi Yaklaşımı, VI. Ulusal Ekonometri ve İstatistik Sempozyomu, Düzenleyen: Gazi Üniversitesi, Ankara.

Garanti Finansal Kiralama A. Ş. (2016). Leasing nedir?, Erişim Tarihi: 21.03.2016, http://www.garantileasing.com.tr/sayfa-detay/leasing-nedir-/45

Gülenç, İ. F. ve Karabulut B. (2005). Doğrusal Hedef Programlama İle Bir Üretim Planlama Probleminin Çözümü, Kocaeli Üniversitesi Sosyal Bilimler Enstitüsü Dergisi, 9(1), 55-68.

Hwang, C. L., \& Yoon, K. (1981). Methods For Multiple Attribute Decision Making, In Multiple Attribute Decision Making, Berlin: Springer.

Karayalçın, İ. İ. (1979). Harekat Araştırması (Yöneylem Araştırması), İstanbul: Fatih Yayınevi.

Kaya, F. (2012). Uluslararası Ticaret İşlemleri ve Muhasebesi, İstanbul: İstanbul Serbest Muhasebeci Mali Müşavirler Odası Yayınları (ISSMMO), Mevzuat serisi.

Kuruüzüm, A. ve Atsan, N. (2001). Analitik Hiyerarşi Yönetimi ve İşletmecilik Alanındaki Uygulamaları, Akdeniz Üniversitesi İ.I.B.F. Dergisi, 1(1), 83-105.

Lai, Y. J., Liu, T. Y., \& Hwang, C. L. (1994). Topsis for MODM, European Journal of Operational Research, 76(3), 486-500.

Mahmoodzadeh, S., Shahrabi, J., Pariazar, M., \& Zaeri, M.S. (2007). Protect Selection by Using Fuzzy AHP and TOPSIS Technique, World Academy of Science, Engineering and Technology, 30, 333-338.

McGuigan, J. R., Moyer, C.R., \& Harris, F. H. B. (1996). Managerial Economics, Minneapolis: West Publishing Company.

Özulucan, A. ve Özdemir, F. S. (2009). Finansal Kiralama Şirketlerince Uygulanacak Yeni Tekdüzen Hesap Planı ve İzahnamesi Çerçevesinde Finansal Kiralama İşlemlerinin Muhasebeleştirilmesi, Ticaret ve Turizm Eğitim Fakültesi Dergisi, 1, 25-43. 
Rouyendegh, B. D. ve Erkan, T. E. (2010). Ankara'da Bulunan 4 Yıldızlı Otellerin, VZA-AHS Sıralı Hibrit Yöntemiyle Etnik Değerlendirilmesi, Gazi Üniversitesi İtisadi ve İdari Bilimler Fakültesi Dergisi,12(3), 69-90.

Saat, M. (2000). Çok Amaçlı Karar Vermede Bir Yaklaşım: Analitik Hiyerarşi Yöntemi, Gazi Üniversitesi İ.İ.B.F. Dergisi, 2(2), 149-162.

Saaty, T. L. (1977). A Scaling Method for Priorities in Hierarchical Structures, Journal of Mathematical Psychology, 15, 234-281.

Saaty, T. L. (1988). Mathematical Methods Of Operations Research, New York: Dover.

Söyler, İ. (2007). Mali Teşvik Uygulamalar Açısından Finansal Kiralama (Teori, Uygulama, Sorunlar, Çözümler), Ankara: Yaklaşım Yayıncılık.

Tekin, M. (1999). Kantitatif Karar Verme Teknikleri, Konya: Kuzucular Ofset.

Toroslu, M. V. (1999). Leasing İşlemleri, Vergi Sorunları Dergisi, 128(Mayıs), 111-121.

Toroslu, M. V. (2000). Çă̆daş Finansman Teknikler, İstanbul: Beta Yayınevi.

Tosun, K. (1990). İşletme Yönetimi, İstanbul: İşletme Fakültesi Yayını.

Ulukanlı, H. (1996, Nisan). Türkiye'de Finansal Kiralama (Leasing) Genel Esasları ve Türkiye'deki Uygulama, Türkiye'de Finansal Kiralama-Leasing (Esaslar ve Uygulama) (II) Semineri, İstanbul, 27-38.

Urfalığlu, F. ve Genç, T. (2013). Çok Kriterli Karar Verme Teknikleri ile Türkiye'nin Ekonomik Performansının Avrupa Birliği Üye Ülkeleri İle Karşılaştırılması, Marmara Üniversitesi İ.I.B.F. Dergisi, 15(2), 329-360.

Vanlığlu, S. (2016). Çoklu Karar Verme Yöntemleri ile Alternatif Finansman Kararları ve Bir Kobi'de Uygulama, Pamukkale Üniversitesi Sosyal Bilimler Enstitüsü, İşletme Anabilim Dalı, Basılmamış Yüksek Lisans Tezi.

Yapı Kredi Leasing A. O. (2016). Leasing nedir?, Erişim Tarihi: 21.03.2016, http://www.ykleasing.com.tr/leasing-hakkinda/leasing-nedir.asp

Yaralığlu, K. (2001). Performans Değerlendirmede Analitik Hiyerarşi Proses, Dokuz Eylül Üniversitesi İ.I.B.F. Dergisi, 16(1), 129-142.

Yaralığlu, K. (2010). Karar Verme Yöntemleri, Ankara: Detay Yayıncılık.

Yıldırım, S., Albez, A. ve Küçük, O., (2006). KOBİ'lerde Finansal Kiralamadan (Leasing) Yararlanma Düzeyi: Bir Uygulama, Atatürk Üniversitesi Sosyal Bilimler Enstitüsü Dergisi, 8(2), 345-360. 